\title{
Phytoplankton as Pollution Indicator using Palmer Index of Chulband River, Gondia District. (MS), INDIA.
}

Prashant C. Shahare

D. B. Science College, Gondia.

prashant_26184@rediffmail.com.

\begin{abstract}
:
Assessment of Phytoplankton as pollution indicator using Palmer index were carried out at 8 stations during throughout the two year samples were collected at monthly intervals during Feb-2010 to Jan-2012 from different water bodies of Chulband River in Gondia district. In this paper Palmer pollution index indicates that organic pollutants contaminate the Chulband River. Palmer's algal genera pollution index varies in between 5 to 28.6 which indicates organic pollution in some stations. Some have probable evidence of high organic pollution and some have lower figure which indicates that the pollution is less. Spatially and temporarily, certain plankton genera are present in common which include like Ankistrodesmus, Chlorella, Closterium, Euglena, Navicula, Nitzschia, Oscillatoria, Phacus, Phormidium, Scenedesmus, Stigeoclonium and Synedra. In the study sites of Chulband River indicates that the water is exposed to organic pollution except Jambhali and Chulband dam stations. Continuous monitoring of the river is necessary.
\end{abstract}

Keywords: Phytoplankton, Palmer's Algal Genus Index, Chulband River, Gondia.

\section{Introduction}

Water resources are being polluted day by day, due to increased human population, industrialization uses of fertilizers in agriculture and other man made activity is one of the reasons for the pollution of water bodies. The growth and abundance of each and every algal form in a fresh water body is influenced by several environmental factors of which the chemical constituents of water body is of prime importance. The knowledge of river phytoplankton in India is fragmentary, though a number of contributions are available (Singh and Srivastava, 1988; Misra et al., 1999; Sridhar et al., 2006). In a water body there usually occur a seasonal qualitative fluctuations in planktonic population in tropical and temperate climates (Jhingran, 1980; Tiwari and Chauhan, 2006). There are few reports on algal pollution (Fogg, 1960; Reimer, 1965; Palmer, 1969, 1983; Hosmani and Bharti 1980; Kant, 1983; Whitton, 1975; Shubert, 1984; Joy and Joseph, 1995; Sudhakar et. al. 1994; Saha et.al. 2000; Dwivedi and Pandey 2002; Mahadev and Hosmani, 2005 Pramila et. al. 2008). In Gondia, Cherian and Shahare, (2011) reported 18 forms of algae of which 9 belongs to Cyanophyceae, 3 to Chlorophyceae and 6 to Bacillariophyceae were reported from Chulband River, Gondia district. Shahare and Cherian, (2012) reported 20 forms of desmids were observed from Chulband River, Gondia district. Shahare and Cherian, (2012) reported 32 forms of Cyanophyceae were observed from Chulband Dam, Gondia district. The physicochemical characteristic of water plays an important role in algal biodiversity and it determines the algal bloom of any specific species. Phytoplankton communities respond quickly to anthropogenic inputs of nutrients and toxic substances making them good indicators of changes in environmental water quality. Stresses caused by these wastes, have a variety of effects on faunal and floral communities living therein which may result in either declining their number severely or eliminating them altogether. There exists a correlation between the intensity of pollution and organisms living therein. Palmer (1968) made the first attempt to identify and prepare a list of genera tolerant to organic pollution.

The present investigation has been based on the data generated from Feb-2010 to Jan2012 from different water bodies of Chulband River in Gondia and numbers of algal species have been identified which are useful indicator of pollution in river.

\section{Material and Methods}

A. Collection: For qualitative study of Phytoplankton, samples were collected at monthly intervals from the selected spots during Feb 2010 to Jan 2012 of Chulband River. In all eight sites were selected along the length of the river falling in the districts for the present study. The sites were 1.Jambhali 2.chulband dam 3.NH. (highway road) 4.Murpar 5.Bothali 6.Sadak Arjuni- I 7.Sadak Arjuni- II 8.Saundad (Table no.1). The different forms such as phytoplankton, epiphytic, epilethic \& floating forms of algae were collected in acid washed bottles \& they were preserved in $4 \%$ formalin for further study of investigation. 
B. Identification: The algal taxa were identified with the help of relevant monographs \& standards literatures (Desikachary, 1959; West and West, 1905; Bruhl and Biswas, 1926; Prescott, 1951, 1975; Turner, 1978; Brook, 1981; Gerrath, 2005;
Brook and Johnson, 2002; Coesel and Meesters, 2007). All identified taxa recorded were arranged taxonomically in table- 2 .

C. Site map: The map illustrate the location of Gondia District, (MS) shown in fig. 1 The eight selected spots along the Chulband River.

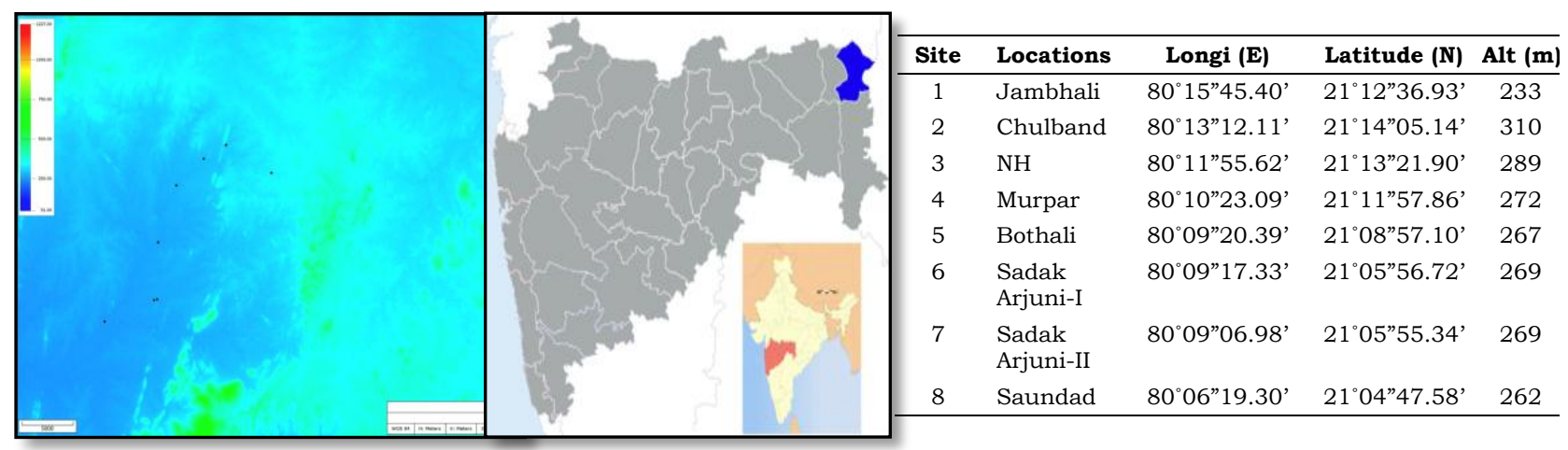

Fig.1 The 8 studied locations from Chulband River, Gondia dist.

Table no.1 Locations (Lat. and Long.)

Table 2: Occurrence of different pollution tolerant phytoplankton in Chulband River,Gondia.

\begin{tabular}{lcccccccc}
\hline Phytoplankton & Jambhali & Chulband Dam & NH & Murpar & Bothali & SA-I & SA-II & Saundad \\
\hline Ankistrodesmus & $\mathrm{P}$ & $\mathrm{P}$ & $\mathrm{P}$ & $\mathrm{P}$ & $\mathrm{P}$ & $\mathrm{P}$ & $\mathrm{P}$ & $\mathrm{P}$ \\
Chlorella & $\mathrm{P}$ & $\mathrm{P}$ & $\mathrm{P}$ & $\mathrm{P}$ & $\mathrm{P}$ & $\mathrm{P}$ & $\mathrm{P}$ & $\mathrm{P}$ \\
Closterium & $\mathrm{P}$ & $\mathrm{P}$ & $\mathrm{P}$ & $\mathrm{P}$ & $\mathrm{P}$ & $\mathrm{P}$ & $\mathrm{P}$ & $\mathrm{P}$ \\
Euglena & $\mathrm{A}$ & $\mathrm{P}$ & $\mathrm{P}$ & $\mathrm{P}$ & $\mathrm{P}$ & $\mathrm{P}$ & $\mathrm{P}$ & $\mathrm{P}$ \\
Navicula & $\mathrm{P}$ & $\mathrm{P}$ & $\mathrm{P}$ & $\mathrm{P}$ & $\mathrm{P}$ & $\mathrm{P}$ & $\mathrm{P}$ & $\mathrm{P}$ \\
Nitzschia & $\mathrm{P}$ & $\mathrm{A}$ & $\mathrm{P}$ & $\mathrm{P}$ & $\mathrm{P}$ & $\mathrm{P}$ & $\mathrm{P}$ & $\mathrm{P}$ \\
Oscillatoria & $\mathrm{P}$ & $\mathrm{P}$ & $\mathrm{P}$ & $\mathrm{P}$ & $\mathrm{P}$ & $\mathrm{P}$ & $\mathrm{P}$ & $\mathrm{P}$ \\
Phacus & $\mathrm{P}$ & $\mathrm{P}$ & $\mathrm{P}$ & $\mathrm{P}$ & $\mathrm{P}$ & $\mathrm{P}$ & $\mathrm{P}$ & $\mathrm{P}$ \\
Phormidium & $\mathrm{P}$ & $\mathrm{P}$ & $\mathrm{P}$ & $\mathrm{P}$ & $\mathrm{P}$ & $\mathrm{P}$ & $\mathrm{P}$ & $\mathrm{P}$ \\
Scenedesmus & $\mathrm{P}$ & $\mathrm{P}$ & $\mathrm{P}$ & $\mathrm{P}$ & $\mathrm{P}$ & $\mathrm{P}$ & $\mathrm{P}$ & $\mathrm{P}$ \\
Stigeoclonium & $\mathrm{A}$ & $\mathrm{P}$ & $\mathrm{P}$ & $\mathrm{P}$ & $\mathrm{P}$ & $\mathrm{P}$ & $\mathrm{P}$ & $\mathrm{P}$ \\
Synedra & $\mathrm{P}$ & $\mathrm{P}$ & $\mathrm{P}$ & $\mathrm{P}$ & $\mathrm{P}$ & $\mathrm{P}$ & $\mathrm{P}$ & $\mathrm{A}$ \\
\hline
\end{tabular}

*P=Present $\mathbf{A}=\mathbf{A b s e n t}$

Table 3: Palmer's Algal Genus Index at different stations of Chulband River, Gondia district.

\begin{tabular}{llll}
\hline Location & Summer & Rainy & Winter \\
\hline Jambhali & $\mathrm{RD}^{*}$ & 5.3 & 15.9 \\
\hline Chulband Dam & 16.6 & 6.1 & 17.5 \\
\hline NH Gondia bridge & 21.0 & 5.9 & 28.4 \\
\hline Murpar & 21.5 & 5.5 & 24.1 \\
\hline Bothali & 25.3 & 5.0 & 28.6 \\
\hline SA-I & 23.6 & 6.5 & 28.1 \\
\hline SA-II & 23.4 & 6.5 & 27.5 \\
\hline Saundad & 21.3 & 7.5 & 19.9 \\
\hline
\end{tabular}

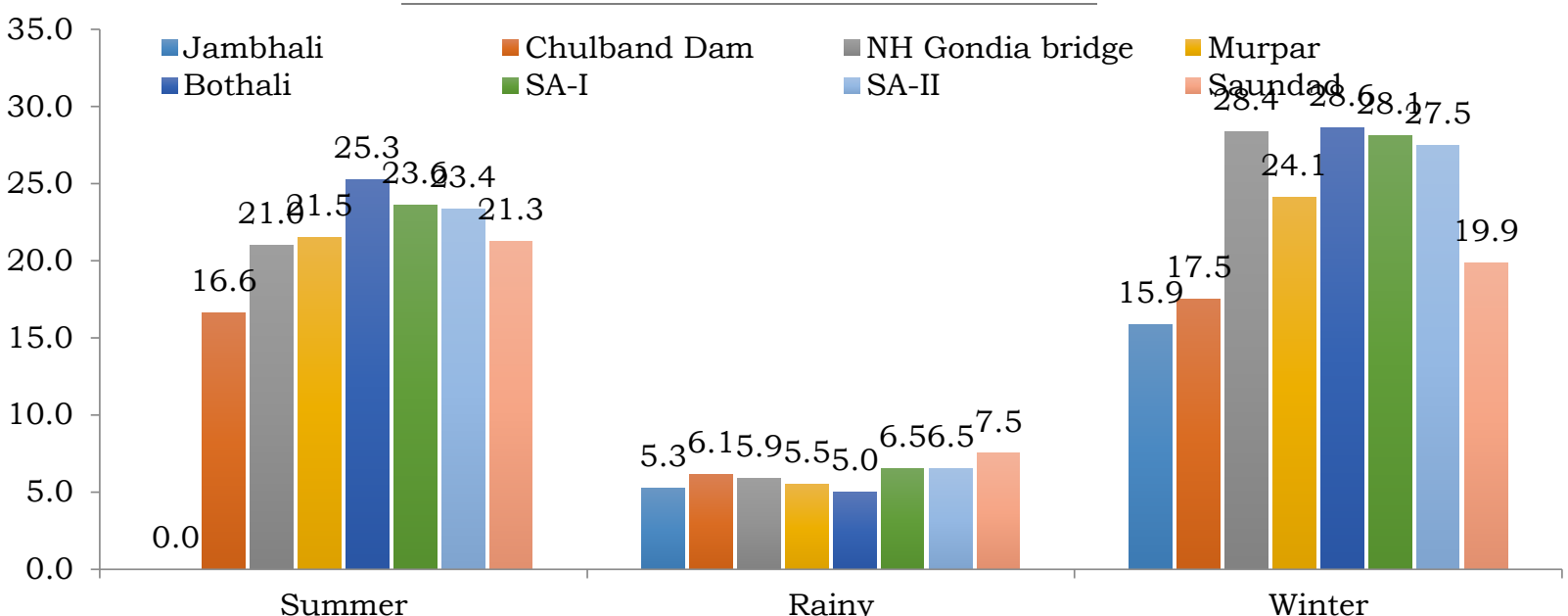

Fig.2: Palmer's Algal Genus Index at different stations of Chulband River, Gondia. 


\section{Result and Discussion}

In the present study, seasonal assessment of organic pollution of the Chulband River has been attempted using Palmer's Algal Genus Index. A score of 20 or more indicate high organic pollution while 15 to 19 indicates probable organic pollution and lower scores usually indicate less organic pollution. Palmer's Algal Genus Index calculated at different stations of Chulband River is shown in table 3. and Fig 2. Spatially and temporarily, certain plankton genera are present in common which include like Ankistrodesmus, Chlorella, Closterium, Euglena, Navicula, Nitzschia, Oscillatoria, Phacus, Phormidium, Scenedesmus, Stigeoclonium and Synedra. Palmer's algal genera pollution index varies in between 5 to 28.6 which indicates organic pollution in some stations. Some have probable evidence of high organic pollution and some have lower figure which indicates that the pollution is less.

The pollution index value during summer season at Jambhali station was dried, at Chulband dam was determined 16.6 which indicates probable organic pollution, at $\mathrm{NH}$ Gondia bridge, Murpar, Bothali, Sadak ArjuniI, Sadak Arjuni-II and Saundad was determined 21, 21.5, 25.3, 23.6, 23.4 and 21.3 respectively, which indicates high organic pollution.

During rainy season, a pollution index value at Jambhali, Chulband dam, NH Gondia bridge, Murpar, Bothali, Sadak Arjuni-I, Sadak Arjuni-II and Saundad was determined 5.3, $6.1,5.9,5.5,5,6.5,6.5$ and 7.5 respectively, which indicates less organic pollution. Increased discharge and dilution occurred as a result of rainfall might have improved the water quality.

The pollution index value during winter season at Jambhali and Chulband dam was determined 15.9 and 17.5 respectively, which indicates probable organic pollution, at $\mathrm{NH}$ Gondia bridge, Murpar, Bothali, Sadak Arjuni-I, Sadak Arjuni-II and Saundad was determined 28.4, 24.1, 28.6, 28.1, 27.5 and 19.9 respectively, which indicates high organic pollution. Warren (1971) pointed out that continued persistence of a species or genera at a particular location is sure evidence that conditions in that environment are favorable for its existence, but its absence does not mean that the unfavorable conditions prevail.

\section{Conclusion}

The results of this investigation provide useful information about the relationship between the physico-chemical properties of the Chulband River with the algal species surviving in the water bodies. The river waters contain various algae which indicate the level of pollution. Phytoplanktons are common like Ankistrodesmus, Chlorella, Closterium, Euglena, Navicula, Nitzschia, Oscillatoria, Phacus, Phormidium, Scenedesmus, Stigeoclonium and Synedra. Palmer's algal genera pollution index varies in between 5 to 28.6 which indicates organic pollution in some stations. Some have probable evidence of high organic pollution and some have lower figure which indicates that the pollution is less. Palmer's Algal Genus Index values can be effectively used to demarcate the areas of a water body which is susceptible to organic pollution. Plankton communities are highly sensitive to changes occurring in the water body and they can indicate the changes before the visible effects which we are facing in the water of the Chulband river Gondia district.

\section{References:}

Brook, A. J.; The Biology of Desmids. Vol. 16, University of California Press, USA. (1981).

Brook, A.J. and L.R Johnson.; Order Zygnematales. 1n: The Freshwater Algal Flora of British Isles John D.M, B.A. Whitton and A. J. Brook (Eds.) Cambridge University Press, UK, PP: 49-593. (2002).

Cherian, K.J. and Shahare, P.C.; "Pollution a threat to conservation of Chulband River, Gondia dist. Maharashtra". ESSENCE- International Journal for Environmental Rehabilitation and conservation Vol. II No. 2: 70-78. (2011).

Coesel, P.F.M. and K. Meesters,; Desmids of the Lowlands. KNNV Publishing, Zeist, Netherlands. (2007).

Desikachary TV; Cyanophyata. ICAR, New Delhi. 4. (1959).

Dwivedi, B. K. and G. C. Pandey; Physicochemical factors and algal diversity of two ponds, Faizabad, India. Poll. Res. 21:361-369. 5. (2002).

Fogg, G. E.; In Proc. Symp. Algology, Vol.1,Issue.VII/Jan 2012;ICAR, New Delhi, 138141. 6. (1960).

Gerrath J.F.; Conjugating Green Algae and Desmids. In: Freshwater Algae of North America: Ecology ard Classification, Wehr, J.D. and R.G. Sheath (Eds.). Academic Press, USA., pp: 353381. (2005). 
Hosmani, S. P. and S. G. Bharti; Phycos 19 (1):23-26. 8. (1980).

Jhingran, V.G.: Fish and Fisheries of India. Hindustan Publ. Corp, Delhi (1980).

Joy, C. M. and A. Joseph; Diatoms as indicator of water quality. Ibid. 170-175. 10. (1995).

Kant Shashi; Algae as indicators of organic pollution. All India Appl. Phyco. Cong. 77-86. 12. (1983).

Mahadev, J. and S. P. Hosmani; Algae for biomonitoring of organic pollution in two lakes of Mysore city. Nat. Environ. Pollut. Technol. 4:9799. 13. (2005).

Misra, A.P., B.K. Borugh and M. Sarma: Limnological investigation of a fresh water tributary. J. Freshwater Biol., 2, 1-5 (1999).

Palmer, C. M,; Keys to water quality indicative organisms (South Eastern United States) Dept. of Interior, Federal Water Pollution Control Administration, Ohio, U.S.A. (1968).

Palmer, C. M.; A composite rating of algae tolerating organic pollution. J. Phycol. 5: 78-82. 16. (1969).

Pramila Kumari, Sharda Dhadse, P.R. Chaudhari and S.R. Wate; A Biomonitoring of Plankton to assess quality of water in lakes of Nagpur city, (ed. M.Sengupta and R. Dalwani). The 12th World Lake Conf. 160-164. 17. (2008).

Prescott G W.; Algae of the Western Great Lakes Area. Michigan State University, USA. pp998. (1975).

Prescott G.; Algae of the Western Great Lakes Area. Cranbook Institute of Science, Boomfield Hills, Michigan. (1951).

Reimer, C. W.; In Biol. Prob. Wat. Poll. (ed. Tarzwell et. al.), U. S. Deptt. Health Edu. And Welfare, Cincinnati, Ohio. (1965).

Saha, S. B., S. B. Bhattacharya and A. Chaudhari; Diversity of phytoplankton of sewage pollution brakish water tidal ecosystem. Environ. Biol. 21 (10: 9- 14. 22. (2000).

Shahare P. C. and Cherian K. J.; "Desmid flora of Chulband River, Gondia district, Maharashtra (India)" Bionano Frontier, Vol. 5 (2-II): 263-268. (2012).

Shahare P.C. and Cherian K.J.; "Study of Cyanophycean diversity at Chulband Dam, Gondia Dist. (M.S.), India." Bionano Frontier, Special Issue-9 (128-130). (2012).

Shubert. L. E.; Algae as ecological indicators. Acad. Press, London. (1984).

Singh, S.R. and V.K. Srivastava: Variation in water quality of Ganga river between Bauxar and Balia. Pollut. Res., 7, 85-92 (1988).

Sridhar, R., T. Thangaradjou, S. Senthil Kumar and L. Kannan: Water quality and phytoplankton characteristics in the Palk Bay, southeast coast of India. J. Environ. Biol., 27, 561-566 (2006).

Sudhakar G., B. Jyothi and V. Venkateswarlu; Role of diatom as indicator of polluted gradients.
Environ. Monit. And Assessment. 33:85-99. 21. (1994).

Tiwari, Ashesh and S.V.S. Chauhan: Seasonal phytoplanktonic diversity of Kitham lake, Agra. J. Environ Biol., 27, 35-38 (2006).

Turner, W.B.; Freshwater Algae of East India (Principally Desmidieae) of East India. Bishen Shingh Mahendra Pal Singh Publication Dehrudun, India. (1978).

Warren, C. E., Biology and Water Pollution Control. W. B. Saunders Co. Philadelphia. xvi434 p. (1971).

West W. and G.S. West; A Monograph of the British Desmidiaceae-II Adlard and Son, London. (1905).

Bruhl, P. and K. Biswas; Algae of the Lotak Lake. Mem. Asiat Soc. Bengal, 8:257-316. (1926).

Whitton, B. A.; In Biolological indicators of water quality. (ed. A. James and L. Erison) Jhon Wiley $\&$ sons, New York (1975). 